\title{
WADAH AKTIVITAS MASYARAKAT DI RAWA BELONG
}

\author{
Keane Martin ${ }^{1)}$ \\ 1) Program Studi S1 Arsitektur, Fakultas Teknik, Universitas Tarumanagara, keanemartin.km@gmail.com
}

\begin{abstract}
Abstrak
Third place merupakan tempat untuk berkomunikasi, beraktifitas, mencari suasana yang asri, tenang, dan menyegarkan pikiran. Secara luasnya di Jakarta membutuhkan third place karena Jakarta sendiri memiliki isu yang cukup meresahkan masyarakat Jakarta, salah satunya yaitu isu kemacetan. Penulis mengambil Kawasan Rawa belong karena di Rawa Belong merupakan kawasan yang padat sehingga daerah tersebut dipadati program yang mendekati Third place. Rawa Belong merupakan Kawasan yang padat akan berbagai sektor, yaitu sektor ekonomi, Pendidikan, dan indsutri. Kawasan tersebut dipadati oleh pemuda-pemuda yang bersifat heterogen dan penduduk lokal. Dengan adanya aktivitas yang sering dilakukan adalah berkomunikasi serta bersosialisasi. Maka otomatis, Rawa Belong dipadati oleh aktivitas kerja kelompok dan bernongkrong. Namun, Rawa Belong terdapat fasilitas yang belum cukup nyaman untuk digunakan. Sehingga terdapat fasilitas yang standar kebersihannya kurang. Adapula kekurangan ruang yang bisa dipakai, berhubung fasilitas disana mudah padat. Rawa Belong tersebut terdapat pasar bunga Rawa belong yang terkenal bahkan sampai dikenal internasional maka penulis mengambil tema pasar bunga sebagai program utama untuk tema Third place. Salah satu isu yang sudah umum yang merugikan masyarakat yaitu polusi udara. Kawasan tersebut merupakan Kawasan padat, maka otomatis Kawasan tersebut cukup berpolusi. Untuk menanggulangi isu tersebut penulis membuat desain bangunan yang ramah lingkungan dan menghadapi isu tersebut. Ide konsep tersebut adalah Biophilic Design dengan objek bunga. Dengan adanya ide konsep tersebut memberi dampak positif terhadap psikologis manusia. Berhubung psikologis di Rawa Belong. Sudah pasti akan memiliki psikologi yang negatif.
\end{abstract}

Kata Kunci: aktivitas; kawasan; komunikasi; psikologi; Rawa Belong

\begin{abstract}
Third place is a place to communicate, activity, find a beautiful atmosphere, calm, and refresh the mind. The area in Jakarta needs a third place because Jakarta itself has an issue that is quite disturbing the people of Jakarta, one of which is a congestion issue. The author takes the area of Rawa belong because in Rawa Belong is a dense area so the area is in a program that approaches Third place. Rawa Belong is a dense area of various sectors, namely the economic sector, education, and Industry. The area is crowded with heterogeneous youths and local residents. With the frequent activities is communicating and socializing. So automatically, Rawa Belong is packed by group work activities and hang out activities. However, Rawa Belong has a facility that is not yet comfortable enough to used. There are facilities that the standard hygiene is lacking. There are also lack of usable space, because there has an easy solid facility. Rawa Belong have the famous Rawa belong flower market even to be known internationally then the author took the theme of flower market as the main program for the theme Third place. One of the issues that is common that is detrimental to the community is air pollution. The area is so dense area, so automatically the region is quite polluting. To decrease the issue the author making the design of the building that environmentally friendly and faces the issue. The idea of the concept is Biophilic Design with floral objects. With the idea of the concept positively impacts human psychologically. Because of psychological in Rawa Belong. It will certainly have negative psychology.
\end{abstract}

Keywords: activity; comunication; psychological; concept; Rawa Belong 


\section{PENDAHULUAN}

Kesemrawutan yang terjadi pada kawasan Rawa Belong menyebabkan aktivitas-aktivitas berada disana menjadi terbatas. Karena semakin banyak transportasi maka semakin sempit ruang untuk pejalan kaki. Tidak hanya itu, karbon monoksida yang dihasilkan oleh kendaraan menyebabkan polusi udara. Dengan kemacetan tersebut, memberi pengunjung disana cukup sulit untuk bepergian. Maka mereka akan memilih meluangkan waktu di kafe, kantin dan minimarket.

Namun, dengan fasilitas-fasilitas tersebut, apakah fasilitas itu sudah menjawab kebutuhan masyarakat? Apakah sudah nyaman untuk dipakai? Jawabannya belum, karena tingkat masyarakat yang berada di Rawa Belong cukup tinggi, dipadati dengan mahasiswa-mahasiswi dan masyarakat lokal. Maka, fasilitas tersebut mudah ramai. Sehingga dibutuhkan suatu ruang yang mampu menampung kapasitas yang cukup besar. Ruang itu adalah ruang publik.

Minimnya ruang publik sebagai akibat pengembangan yang hanya berorientasi padaa kepentingan kapital, mengakibatkan masyarakat mengatasinya secara mandiri. Mereka mengadakan sendiri ruang publik di lingkungan permukimannya dengan kemungkinan akses yang lebih besar. Sebuah lapangan terbuka di tengah permukiman misalnya, tidak jarang menjadi ajang sosialisasi para warga.

Jalan-jalan dalam Rawa Belong dipenuhi dengan berbagai macam kantin, kafe, dan restoran. Di Rawa Belong terdapat fasilitas pendidikan yang terkenal yaitu Sekolah Tarsisius, Bina Nusantara hingga perkampungan Rawa Belong di fungsikan sebagai kantin, kafe, dan warung internet. Hal ini difungsikan untuk menyediakan jasa yang dibutuhkan mahasiswa-mahasiswa.

Penulis mengusulkan konsep Biophillic design sebagai konsep utama untuk ruang ketiga ini. Dan juga menawarkan program-program yang tentunya tidak beda jauh dengan fasilitas-fasilitas yang ada di kawasan ini, contohnya kafe. Secara morfofologinya mengikuti objek bunga sebagai pendukung konsep Biophillic. (Finnegan, 2011)

\section{Design Vision \& Idea}

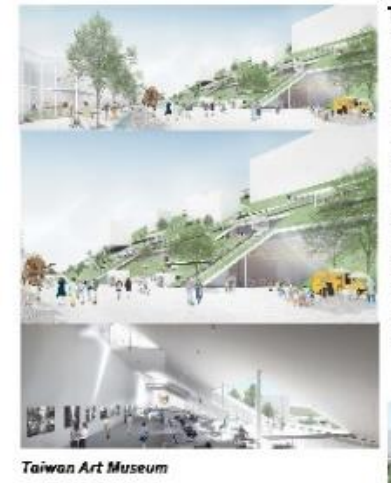

\section{Biophilic Design}

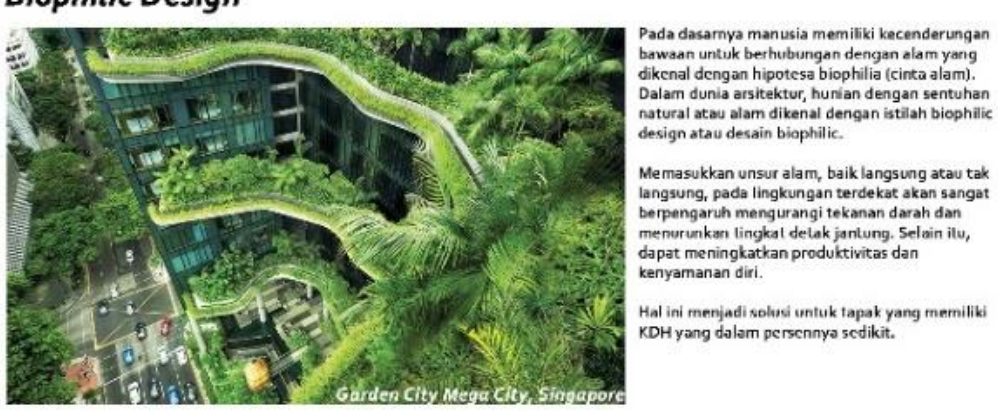

Gambar 1. Skema Konsep

Sumber: Penulis, 2019

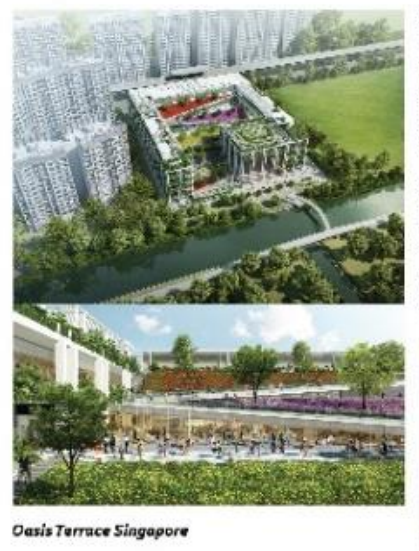

Oasis Terrace Singapore

Dalam oasis terrace tersedia fasilitas kasehatan, sementera sisanye akan mencakup kebur komunal, ruang bermain, gimnasium, rvang ritel,
ruang makan, dan ruang belajar, yang semuanya diharapkan datang bersama menjadi "generasi beru pembangunan letpadu." Seluruh proyek akan terhubung melalui jalur toko-toko, kafe, food court, pusat pendidikan dan rvang poliklinik. Bentuk bangunan yang miring digunaka

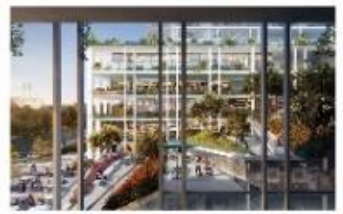

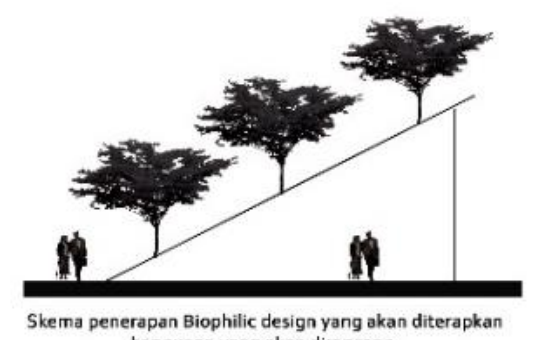

bangunan yang akan dirancang. 


\section{KAJIAN LITERATUR}

\section{Open Architecture (The architecture for Third place)}

The Third place adalah ruang/tempat berkumpul/beraktivitas serta komunitas masyarakat selain rumah (the first place) dan tempat bekerja (the second place). Banyak pengamat yakin bahwa hilangnya tempat komunitas untuk, berkumpul, beraktivitas dan berinteraksi inilah yang dicari oleh masyarakat yang tinggal di daerah sub-urban dan daerah pinggir kota.

Ruang publik adalah tempat dimana orang pergi dengan tujuan tertentu. Untuk mencari suasana yang tenang, orang pergi ke taman-taman, untuk melakukan perdagangan, orang pergi ke pasar. Kita menghabiskan waktu di tempat-tempat publik tersebut karena kebutuhan kita bukan karena suatu keharusan. Ruang publik menarik karena memberi kesempatan untuk terjadi interaksi. Sejauh ini belum ada sebuah formula atau rumusan khusus untuk menciptakan ruang publik yang berhasil. (Oldenburg, 1989)

Pernahkah mengamati layout ruang pada Starbucks? Di Starbucks, terdapat sebuah meja besar, yang tidak terdapat pada café lainnya ? Bila diamati lebih mendalam, ternyata meja besar mendominasi ruang dining/makan dan berada di posisi tengah dikelilingi oleh meja-meja untuk 4 orang. Kenapa Starbucks mendesain seperti itu? Pengunjung Starbucks bukan hanya duduk untuk menyeruput kopi (makan dan minum) dan mengobrol dengan teman (rendezvous) akan tetapi mereka juga bekerja dan berdiskusi. Ada beberapa catatan yang mungkin berpengaruh pada pembentukkan ruang starbuck. Starbucks menjadikan ruang "café" menjadi sebuah place tanpa menghilangkan cafenya. Meja kecil kemudian digantikan menjadi meja besar, merupakan respon perancang terhadap kegiatan Bersama yang tidak mungkin dilakukan pada meja kecil (shareable place). Meja besar yang menjadi center mengeser tempat pembuatan kopi dimana seharusnya menjadi hal utama (center = utama).

Space menjadi place tidak hanya terjadi pada tingkat kompleksitas rendah seperti café, akan tetapi juga pada komplekitas yang lebih besar, seperti kantor. (Schulz, 1976). Umumnya, kegiatan kesehariannya manusia bekerja dengan produktivitas tinggi, sehingga diperlukan sarana kerja yang sesuai dengan gaya hidup para pekerjanya sehingga dapat meningkatkan produktivitas. Kantor yang berarti administrasi atau birokasi, mulai bergeser dari artinya terkait dengan ruang kerja menjadi tempat untuk kerja. Tempat kerja menyerap berbagai macam program di luar dari kebiasaan dari tipologi kantor. Fitnes, kantin, tempat bermain, bahkan tempat tidur menjadi bagian dari tempat kerja, dengan tujuan agar bekerja itu menjadi menyenangkan, bahkan menjadi rumah kedua dari pekerjanya. Kantor seperti ini membuat sebuah komunitas, dimana diharapkan bila pekerja didalam komunitasnya dapat bekerja lebih nyaman dan produktif. (11architecture, 2017)

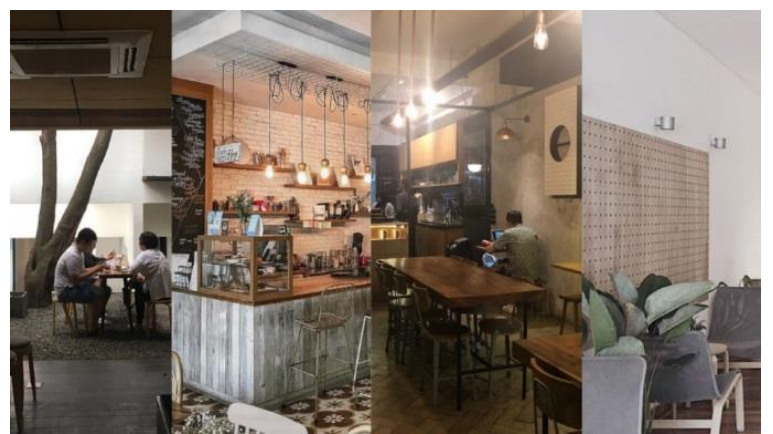

Gambar 2. contoh café

Sumber: www.google/coconut.com diunduh 19 Agustus 2019

Kedua contoh diatas merupakan perubahan dalam arsitektur yang meninggalkan atau meredifinisi tipologi lama. Café sebagai work place dan kantor yang menjadi work and leisure. Tentunya café tidak dapat menggantikan tempat kerja dan leisure tidak dapat menggantikan kantor secara keseluruhan, akan tetapi kedua tempat itu membentuk objek arsitektur yang disebut dengan Third place. 


\section{Third place di Indonesia}

The third place adalah tempat penting yang merupakan kebutuhan masyarkat, selain dari rumah (the first place) maupun tempat kerja (second place). Third place adalah tempat publik yang netral, sebagai tempat alternatif, dapat digunakan siapa saja.

Third place ada dimana-mana dan memiliki bentuk yang beragam sesuai dengan kehidupan dan budaya masyarakatnya.

Indonesia memiliki third place, seperti banjar pada desa bali, bale di desa jawa, rumah tradisional di Kalimantan dan di berbagai komunitas lainnya, dimana masyarakat dapat berkumpul membicarakan berbagai macam hal tentang masyarakatnya. Di Indonesia, third place ini biasanya hanya tempat terbuka yang diberi atap, kecuali di masyarakat Dayak, berbentuk rumah besar. Posisi third place memiliki nilai strategis dan pada posisi penting pada compound masyarakatnya karena makna dan symbol kronologisnya. Didalam konteks masyarakat kota, The third place telah kehilangan maknanya, karena masyarakat kondisi pekerjaan maupun kehidupan kota yang tidak seteratur di pedasaan. Masyakarat kota kemudiaan lebih mencari hiburan atau bertemu dengan teman di pusat perbelanjaan. Kondisi ini menyebabkan menjamurnya pemusatan-pemusatan program komersial seperti mall. Karena dengan banyaknya atraksi dan market gimmick menyebabkan hilangnya unsur interaksi antar sesame. Interkasi sangatlah diperlukan untuk membina rasa empati, Kepedulian, daya nalar, dan proaktif dan hal-hal terhadap sesame manusia. Karena itu the third place diperlukan, namun tentunya didalam konteks masyarakat kota dan perkotaan.

Di jakarta sendiri tidak terlepas dari fenomena Tempat ketiga (Third place). Pasalnya bertambah banyak program seperti mall-mall, kafe, resto dan coffee shop yang memberi pilihan tempat untuk berkumpul, bersosialisasi, dan rekreasi. Fenomena ini disebut fenomena nongkrong. Karena sudah menjadi kebudayaan masyarakat local maupun luar. Perilaku ini tidak bisa dianggap sekedar budaya yang konsumtif dan negatif. Bahkan kedai-kedai kopi banyak di kelola oleh anak-anak muda yang memang dekat dengan budaya nongkrong. Sehingga memberi keuntungan tidak hanya dari segi ekonomi namun juga dari pemanfaatan ruang kota. Ruang-ruang kota yang sebelumnya sepi menjadi ramai, Bangunan yang sebelumnya tidak termanfaatkan menjadi berfungsi kembali (infill), sehingga dapat menjadi solusi dalam menata dan menghidupkan ruang kota menjadi lebih atraktif yang memiliki karakter.

Ditinjau dari jenis ruang, transformasi tempat ketiga awalnya berupa ruang-ruang dalam seperti bangunan seperti restoran, mall mulai mengalami transformasi ke budaya luar, yaitu plaza, taman kota (urban kota), dan jalan (street).

Bagi warga Jakarta Tempat nongkrong yang bagus itu adalah tempat yang menjawab kebutuhan para pelanggan, kita harus paham apa keinginan pelanggan, sehingga ketika mereka kesini, akan meninggalkan kesan yang baik dan rindu ingin kembali lagi.

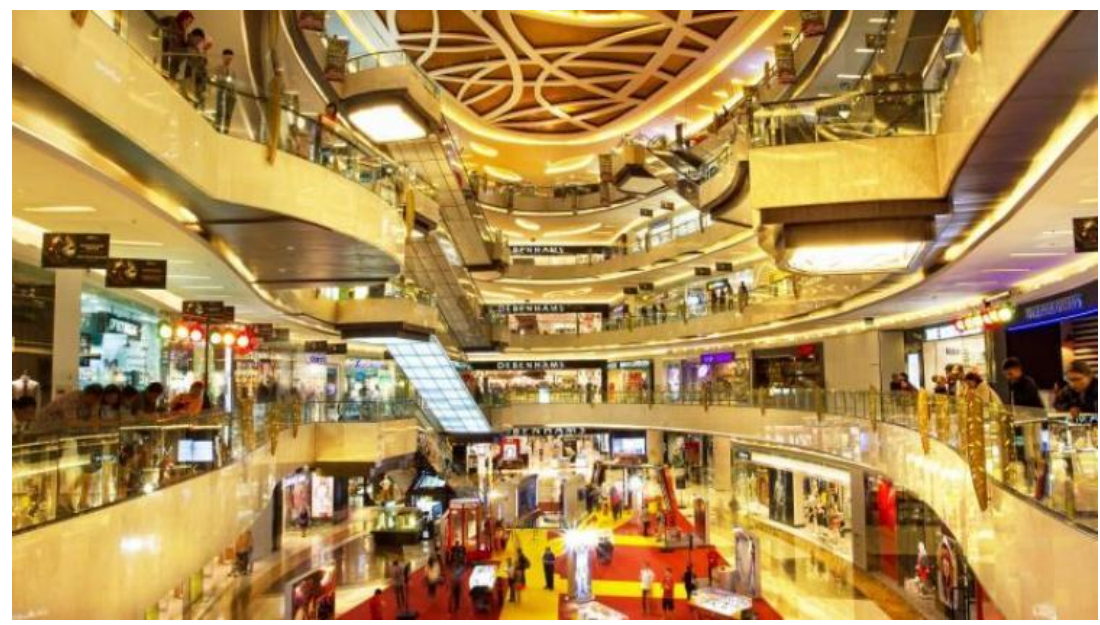

Gambar 3. Shopping Mall di Jakarta

Sumber: www.google/infojakarta.net, diunduh 19 Agustus 2019 


\section{METODE}

Metode merupakan langkah penting untuk mempermudahkan menemukan hasil dari kajian teori, dan isu yang dibahas. Secara rincian, metode ini terdiri dari metode penelitian dan metode perancangan. Dalam metode penelitian ada 2 cara yaitu metode survei dan kuesioner. Dalam metode perancangan ada 2 macam, yaitu metode transformasi dan morfologi.

\section{Metode Penelitian}

Metode yang digunakan yaitu metode survei. Namun tidak hanya survei, pengamatan dan riset juga. Yang penulis lakukan yaitu survei dan menyebarkan kuesioner melalui online. Dalam survei, informasi dikumpulkan dari responden menggunakan angket atau kuesioner yang didistribusikan secara langsung atau melalui perantara seperti telepon atau media online.

Tidak hanya itu penulis juga mendatangi ke lokasi Kawasan tersebut dan mengamati Kawasan yang dipilih tapak. Penulis juga menggunakan pengalaman ketika memasuki dalam kampus Binus, Café di sekitar Binus dan pengalaman dalam berjalan kaki ketika mengelilingi Kawasan Batusari.

\section{Metode Perancangan}

Dalam metode ini, penulis menggunakan 2 metode sebagai pendukung utama konsep. Metode tersebut terdiri dari metode transformasi dan morfologi. Akan tetapi selain itu ada Teknik dasar untuk mendesain yaitu proporsi. Teknik itu digunakan sebagai pedoman untuk menrancang rencana denah bangunan dan merancang bangunan segi eksterior. (Agil, 2014)

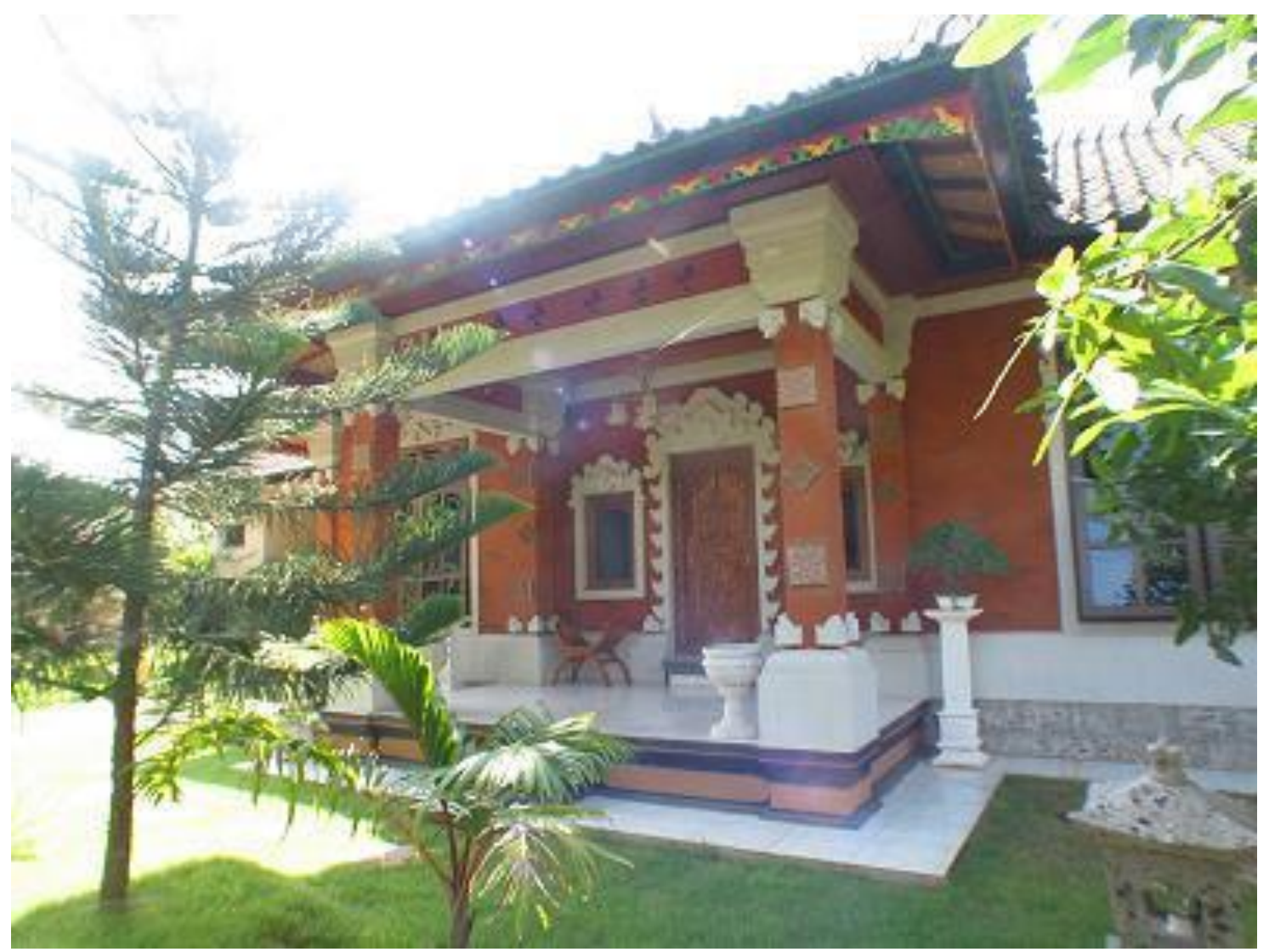

Gambar 4. Tipomorfologi arsitektur

Sumber: (Hartono, 2018) diunduh 15 Agustus 2019 


\section{DISKUSI DAN HASIL}

Dari kajian teori, isu, dan metode serta referensi-referensi yang digunakan, sudah ada ide desain yang akan digunakan. Ide konsep tersebut menghasilkan bangunan serta programprogram yang menyediakan kebutuhan ruang ketiga.

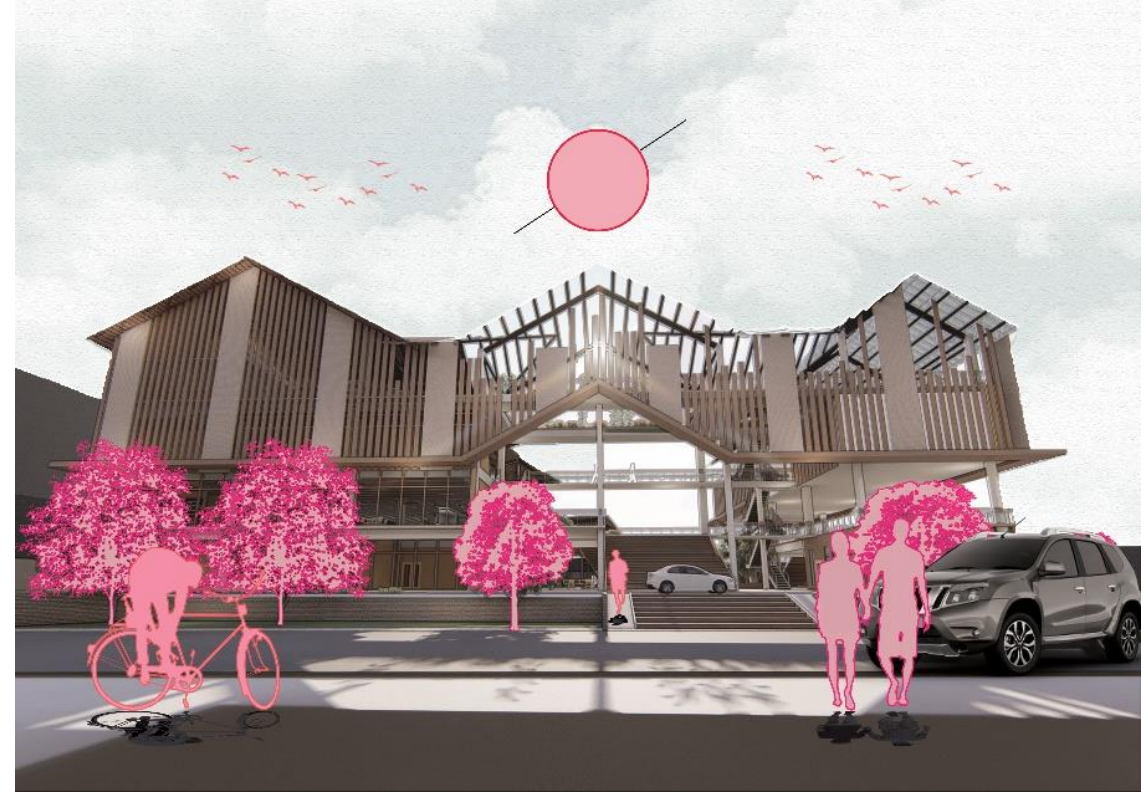

Gambar 5. Lobby view

Sumber: Penulis, 2019

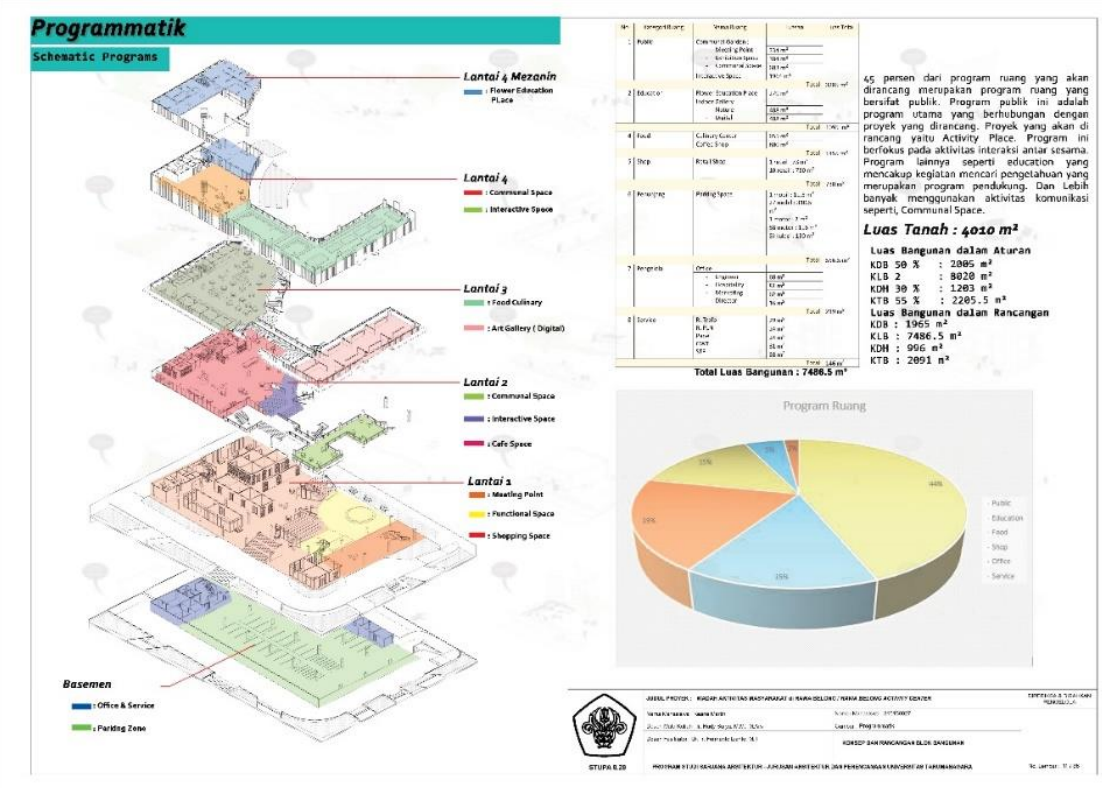

Gambar 6. Program

Sumber: Penulis, 2019

Dari program tersebut, 45 persen dalam bangunan itu fokus terhadap kebutuhan ruang bersifat publik, sehingga dalam program publik itu terdiri dari interactive space, functional space, Shopping space, serta comunal space. Selain itu terdapat juga program penunjang, yaitu eating space dan working space, seperti food court dan café \& co-working space. Tidak hanya itu, tiap bangunan tentunya ada bagian untuk mengurus bangunan, yang disebut pengelola. Bagian pengelola tersebut terletak pada basemen bangunan. Di dalam itu terdapat bagian vital bangunan serta kantor pengelolanya. Ada program yang mempunyai unsur spesial,yaitu comunal space. Disana memberikan aktivitas yang memungkinkan pengunjung untuk berinteraksi terhadap objek bunga atau tanaman. Selayak mendekatkan diri terhadap objek penghijauan. 


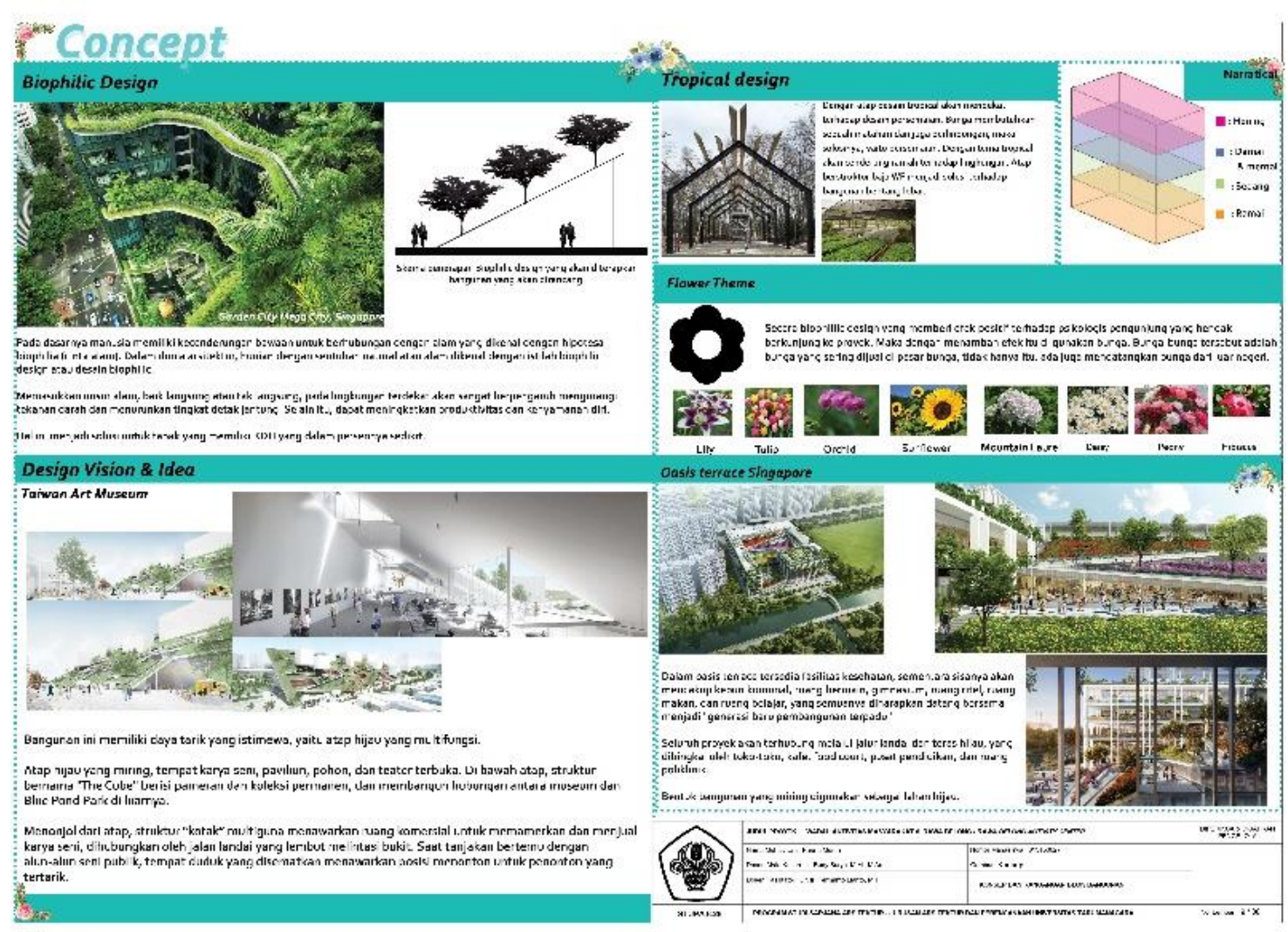

\section{Gambar 7. Konsep Utama}

Sumber: Penulis, 2019

Secara luasnya, konsep utamanya yaitu Biophillic design, (Finnegan, 2011) namun untuk perinciannya yaitu dengan unsur tropikal. Unsur tropikal memang umum untuk bangunan di indonesia. Tetapi hal itu justru memberi kegunaan terhadap bangunan. Dari segi luar maupun dalam, Manfaatnya apa? Menghadapi kondisi lingkungan yang dimiliki Indonesia. Indonesia memiliki 2 musim, yaitu musim kemarau dan musim hujan. Sehingga dengan unsur tropikal itu dapat menghadapi masalah yang diberikan 2 musim tersebut.

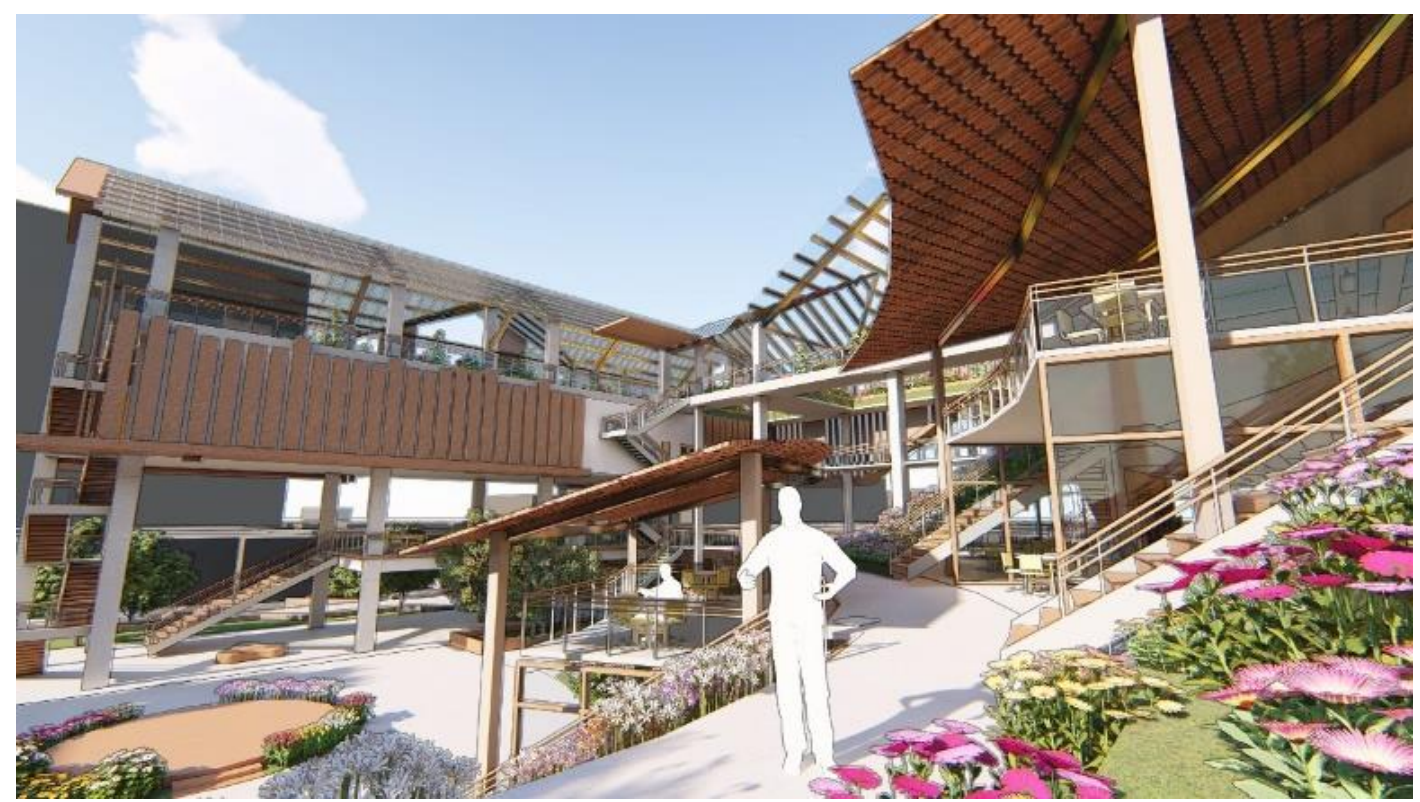

Gambar 8. Interactive Space

Sumber: Penulis, 2019 


\section{KESIMPULAN DAN SARAN}

Objek bunga dalan bangunan memang menarik untuk dilihat, dikunjung, serta memberi dampak postif terhadap pengunjung. Dalam bunga itu mengartikan berbagai macam makna, sehingga diusahakan menanam bunga sesuai dengan zona perletakannya. Namun, dengan adanya program yang 45 persennya bersifat terbuka, akan memberi pengguna untuk merasakan unsur-unsur yang terdapat dalam ruang ketiganya. Program-program ini diusahakan untuk melengkapi atau menyesuaikan dengan aktivitas-aktivitas yang biasa dilakukan oleh wargawarga lokal serta mahasiswa-mahasiswi. Berhubung dengan situasi lingkungan yang terdapat dalam kawasan tersebut memang berpolusi sehingga penggunaan konsep tersebut untuk menanggulangi dampak yang diberikan terhadap isu tersebut.

Dari hasil sidang tersebut, penguji-penguji menyarankan proyek itu tidak menyerupai dengan pasar bunga Rawa Belong. Namun, memang berbeda dari pasar bunga rawa belong, yang berbeda adalah tujuan proyek. Tujuan pasar bunga untuk memperjual belikan dagangan bunga, menyediakan jasa untuk pengucapan selamat, serta jasa untuk pembuatan bunga. Maka, proyek ini bertujuan untuk berwisata, bekerja, mencari suasana yang positif.

\section{REFERENSI}

11architecture. (2017, July 13). SimplyWork 6.0 Co-Working Space / 11architecture. (Archdaily) Diambil kembali dari https://www.archdaily.com/

Agil, D. (2014, Juni 1). Art and Architecture. Diambil kembali dari Art and Architecture - Art can save your life: gagasdhio.wordpress.com

Finnegan, S. R. (2011). BIOPHILIC DESIGN The Architecture of Life Viewing Guide. BIOPHILIC DESIGN.

Hartono, D. (2018). Diambil kembali dari DOCPLAYER: www.docplayer.info

Oldenburg, R. (1989). The Great Good Place. Philadepia: Paragon House.

Schulz, C. N. (1976). Genius Loci-Toward Phenomenology of Architecture. Oslo: Rizzoli. 